\title{
Delivery Of miR-375 And Doxorubicin By Lipid-Coated Hollow Mesoporous Silica Nanoparticles To Overcome Multiple Drug Resistance In Hepatocellular Carcinoma [Corrigendum]
}

\author{
Xue $\mathrm{H}, \mathrm{Yu} \mathrm{Z}$, Liu $\mathrm{Y}$, et al. Int $J$ Nanomedicine. \\ 2017;12:5271-5287.
}

The authors of this paper have advised that Figure $8 \mathrm{E}$ is incorrect. Because of the similar label of groups LHD/ miR-375 and LH/miR-375, the authors uploaded the wrong figure by mistake. The authors have confirmed this correction will not make any change to the conclusion of their original research.

The correct image for Figure 8E is below:

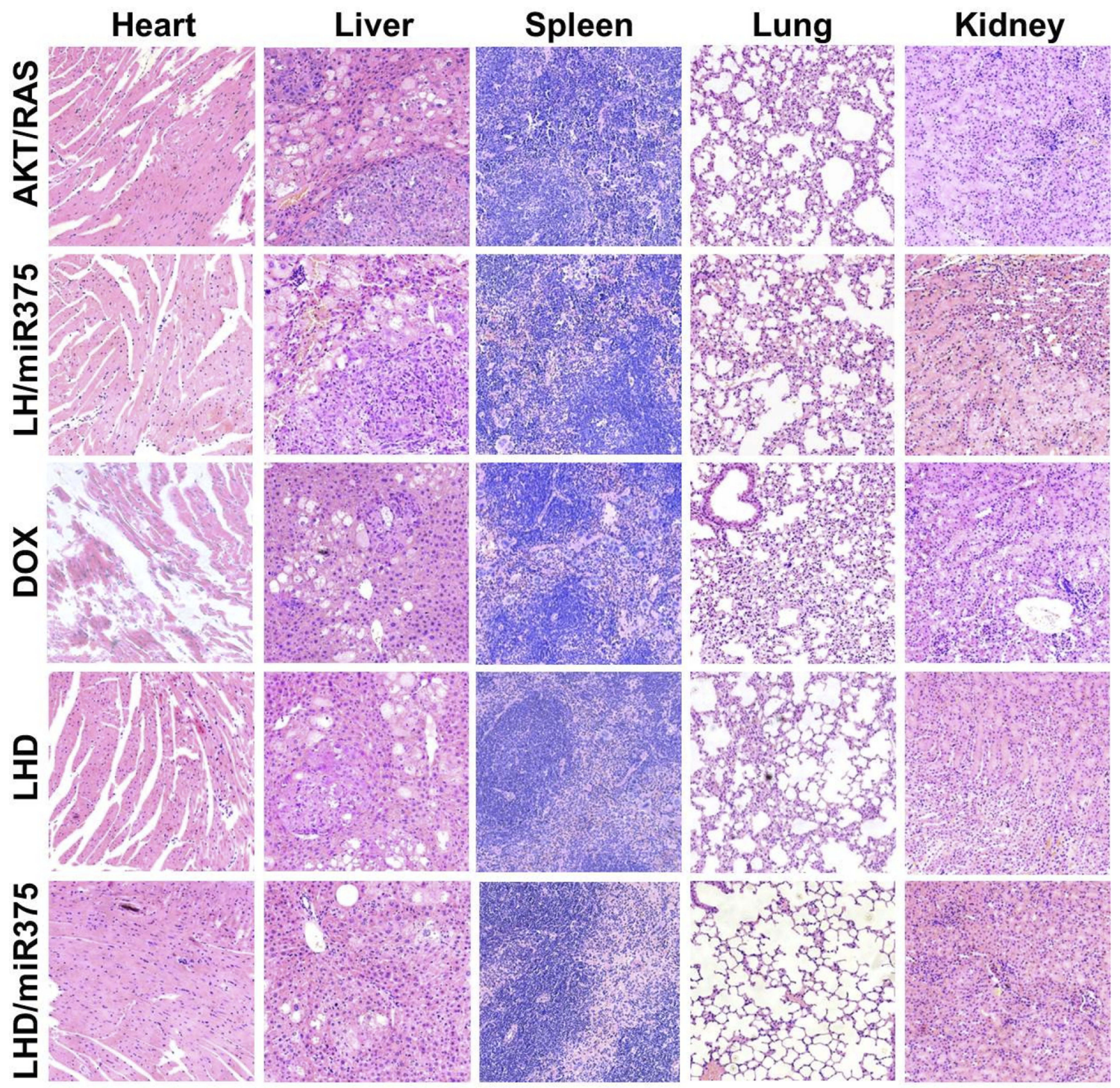




\section{Publish your work in this journal}

The International Journal of Nanomedicine is an international, peerreviewed journal focusing on the application of nanotechnology in diagnostics, therapeutics, and drug delivery systems throughout the biomedical field. This journal is indexed on PubMed Central, MedLine, CAS, SciSearch ${ }^{\circledR}$, Current Contents ${ }^{\circledR} /$ Clinical Medicine,
Journal Citation Reports/Science Edition, EMBase, Scopus and the Elsevier Bibliographic databases. The manuscript management system is completely online and includes a very quick and fair peer-review system, which is all easy to use. Visit http://www.dovepress.com/ testimonials.php to read real quotes from published authors. 